\section{Kristiyanong Pinoy: A glimpse on the history of evangelization towards renewed catechesis in the Philippines}

Quimson, Leonardo O., Jr.

University of Santo Tomas, Philippines (loquimson@ust.edu.ph)

Received: 5 November 2021

Available Online: 2 January 2022
Revised: 29 November 2021 DOI: $10.5861 /$ ijrse.2022.202

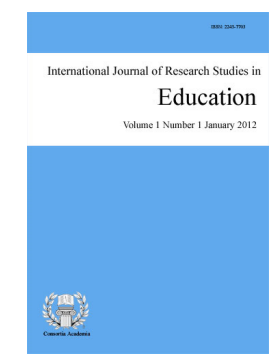

ISSN: $2243-7703$ Online ISSN: 2243-7711

Accepted: 20 December 2021

OPEN ACCESS

\title{
Abstract
}

In 2021, the Philippines makes history and builds milestone for celebrating its 500 years of Christianity. The Filipino faith has been tested through time and became known and recognized in the world. But aside from celebration, it is also a reality that a lot is still to be improved in catechizing the young, for they expect more on the Church to be "guide and companion". This experience also calls for renewal in the Church to make the Gospel known, embraced, and lived upon at present. This study tries to trace back how the Christian faith started in the Philippines through the efforts of people who spread the faith and how it flourished as years went by until the present where the Church, through renewal movements, continues Her mission to all. The researcher uses document analysis approach in collecting and verifying information and faith experiences from resources in Philippine Church history and put side by side with the recent Church documents in the Philippines as way of renewal in catechesis. Finally, it proposes ways to make the teaching of faith more meaningful and effective to learners and, for catechists to be nourished always in this mission they received from Jesus.

Keywords: catechesis, religious education, evangelization, Philippines, history 


\section{Kristiyanong Pinoy: A glimpse on the history of evangelization towards renewed catechesis in the Philippines}

\section{Introduction}

The Church in the Philippines professed that "the Filipinos had a long history of very sharp and colorful religious experiences and the understanding and love for Jesus Christ has been colored by personal and national historical experiences of pain and struggle, of victory and celebration" (CFC, 1997, \#31). This abundant history of the Filipino Christians must be treasured, lived, and proclaimed through memory for "it is an important key for the transmission of God's revelation to keep the Lord's presence always alive in our hearts" (Directory for Catechesis, 2020, \#201). Therefore, the researcher attempts to use the "historical research" as design for the study.

Achas and Salmorin (2014) defined it as a "research design wherein past events are studied and related to the present or in the future time with a purpose of reconstructing the past objectively and accurately" (p. 75). This method "attempts to systematically recapture the complex nuances, the people, meanings, events, and even ideas of the past that have influenced and shaped the present" (Berg \& Lure, 2012, \#1). It also intends to collect, verify, and synthesize evidence from the past to establish facts that defend or refute the hypothesis of the study. It tries to "gather all pieces of information from the past and identify the trends which will be a tool for transformation and change for the better" (Maningas, 2003, p. 79). This approach in research fits in the aim of the study to look back on the richness of the Filipino Christian faith which the Filipino Christian Catholics celebrate with gratitude, reflection, and jubilation.

Cacho (2021) expressed that "faith must take root in the matrix of our Filipino being so that we may truly believe and love as Filipinos. However, for this to happen, the Gospel must be presented and understood with tools, methods, and expressions coming from the culture itself" (p.25). Historical document analysis helps the researcher to look into the grandeur of the Philippine Christian faith and connect it with the current trends and challenges in catechesis or teaching of the faith for "every tradition is a rich source for present and future generations... The Christian story is full of wealth, which we could use to advance in our faith and help us make wise choices at present. No matter how old a treasury is, one could not deny the wisdom contained therein which are ready to be rediscovered and redefined to fit people's contemporary engagements and challenges" (Cacho, 2021, p.41). As the Second Plenary Council of the Philippines or PCP II (1992) addressed to the Filipino people in anticipation of the 500 years of celebrating the faith, "Has that faith, does that faith make any difference in our life and to our nation nowadays?" (\#3), this paper tries to answer the call of the Church to continue the mission of teaching and living the faith by looking at the past with thanksgiving and with courage to continue the mission entrusted by the Lord.

\subsection{The Philippines before the Arrival of the Gospel}

The Philippines celebrates the 500 years of the existence of the Christian faith in the country in 2021. It is truly a milestone and a great way for jubilation "for the Filipino country has not only survived but has been a strong influence in the culture and character of the nation and is still going strong. We are the third country in the world with the most numerous Catholic populations. The Catholic faith and devotion of the Filipinos is recognized all over the world. Through our Filipino migrants and missionaries, we also strengthen the Church in most of the 200 countries all over the world where Filipinos are found" (Catholic Bishops Conference of the Philippines, 2019, \#1).

But now, the question is this. How did the Christian faith flourish in the Philippine soil? How did it all begin? What was the scenario during the time before the Gospel of Jesus Christ came into our land? According to Fr.

12 Consortia Academia Publishing (A partner of Network of Professional Researchers and Educators) 
Kristiyanong Pinoy: A glimpse on the history of evangelization towards renewed catechesis in the Philippines

Pablo Fernandez (1988), he explained that before the coming of the Christian faith, "the Filipinos have already their ideas and practices which were vaguely conceived in various forms due to minimal inter-island exchange among people, the multiplicity of dialects and the never-ending battles among different ethnic groups. He said that beforehand the arrival of the missionaries, the Filipino people already believed in the Supreme Being such as the existence of "Bathala Maykapal" for the tagalogs, the visayan "Laon" as call for the Ancient Being, and the Cabunian for the Ilocanos are names given to the One being without limits, creator of heaven and earth, lawgiver, and judge of all living and of the dead. But aside from the belief in the Supreme Being, Filipinos already practice before polytheism or believing in many deities for they believe that there is a god in every village, mountain, river, reef even rainbow and other natural things.

Moreover, the worshipping of Spirits such as the "anitos" or "diwatas" which the primitive people call for the good spirits is very evident for they treat spirits as messengers to Bathala who sent them as help on earth. In addition, Filipinos did not lack persons assigned to offer prayers to their idols. The reality of having priestesses or "Katalonan" or "Babaylan" were known during those times in presiding over on ceremonies. At the end, the beliefs of the Filipinos before the arrival of Christianity were reflections of primitive revelation" (p. 1-9). Del Castillo (2016 \& 2021) added that "early people of the Philippines had a worldview and religion of their own before the Catholic missionaries came to the Philippines. They have no scripture nor hierarchy and founder. Instead, they have myths, proverbs, custom and codes of conduct in lieu of the sacred scripture" (p. 44).

Aside from these religious practices, "the Filipinos already have the most basic unit of government, the barangay. This was the original name of the boat in which the Malays had come to the Philippines. This unit of government is based on kinship and blood relationship. There is no central government ruling in the nation during those times. Precisely, the political fragmentation facilitated easily the fast and uncomplicated conquest of the country. The people had no sense of being one country during those times and this will give way to the creation of a sense of nation which is the effect of the evangelization of the Philippines" (Gutierrez, 2000, p. 2-9).

\subsection{The Beginning of the Propagation of the Faith: The Coming of the Spaniards}

The Christianization of the Philippines began through the little yet persevering attempts of the missionaries from Spain, a well-known conquering nation in the west. The expedition of Ferdinand Magellan, a Portuguese explorer, "lead the initial establishment of the Christian faith in the Philippines when he sailed from Seville to the Mollucas and Ladrones Islands in the east. On March 16, 1521, after an exhausting voyage across the Pacific Ocean, unexpectedly seen the coast of Samar and from their unstopping disembark, they reached the Homonhon and the island of Limasawa where in the historical first Mass was celebrated on the Philippine soil with the secular priest Fr. Pedro de Valderrama on Easter Sunday, March 31, 1521. After this, Magellan went to the land of Cebu on April 7, 1521, and met the kinglet Raja Humabon and his wife and both received the Christian faith through Baptism" (Fernandez, 1988, p. 10-11).

After the tragic death of Magellan in the battle of Mactan, many other expeditions tried to follow the footsteps marked by Magellan. But the conquest and colonization of the Philippines started earnestly with Miguel Lopez de Legazpi. From Puerto dela Natividad, Mexico, "he sailed together with 350 soldiers and arrived by April 27, 1565, at Cebu wherein they found through his Spanish soldier, Juan Camus, the image of Santo Nińo, the same image given by Magellan to the wife of Humabon, baptized as Queen Juana. In 1571, Legazpi conquered the city of Manila and made it the center of the new Spanish colony. Manila was given a royal charter on June 24. After all these, Spain had come to stay. Legazpi, together with his companions, both conquerors and missionaries, set things in motion to make Philippines to be changed radically. Unfortunately, Legazpi died soon and suddenly on August 20,1572. He died poor but well loved by the people. King Philip II found in Legazpi the right man for a peaceful conquest of the Philippines. He was called "the Great Pacifier" of the Philippines. He became famous by using not the sword of the conquerors but the cross of the missionary" (Gutierrez, 2000, p. 9-12). But on the other hand, aside from the evident and warm acceptance of the Filipinos on 
the Christian faith, it is also clear that "the early Filipinos accepted the Christian religion of Spaniards out of fear and greed. It moved the early Filipinos to accept the Catholic faith. Filipino natives were afraid that they would all be destroyed if they refuse the faith of the visitors... Looking back at the initial encounter of the early Filipinos with Magellan and the baptism of the subjects of Raja Humabon, there was no great tension between being Christian and being member of a cultural group." (Del Castillo, 2016, p. 43-44). At the end, it is also true to say as some historians would describe, that "Christianity is an instrument of colonialism because it shares some blame for the violence, abuses, and oppression that Filipinos experienced at the hands of Spaniards" (Santos, 2021, \#3).

\subsection{The Missionaries and their Apostolic Works in Evangelization and Catholic Education}

The military presence of the Spaniards during her 333 years of stay in the Philippine islands is insignificant but the missionaries' zeal and charity that brought the Filipino people into the fold of the Church. The primary reason of the conquest of Spain to the east, most importantly, is to proclaim and spread the Christian faith. Fr. Lucio Gutierrez (2000) said that "the friars or the missionaries were the main protagonists of the Christianization in the Philippines, the different religious congregations and also some secular clergy" (p. 17). Moreover, according to Fr. Jose Femilou Gutay, OFM as quoted by Pilario \& Vibar (2015), he explained that "the education of the faith during the Spanish colonial rule was within the jurisdiction of the Church. The missionaries established many institutions of learning all over the country as soon as they inaugurated their missionary evangelization in the archipelago" (p. 145).

The first missionaries to come in the Philippines in 1565 were the Augustinians, in the expedition led by Miguel Lopez de Legazpi. As pioneers of Christian faith, "they were men of high learning and prove virtue. To abandon their lives in Europe and sail for the Orient, crossing uncharted seas demanded spiritual generosity. They were men of Renaissance and Catholic Reformation. They settled first in Cebu and constructed a small church and a convent in honor of Santo Nińo. Cebu became the cradle of Christianity in the Philippines. Years after, when Manila was established in 1571 by Legazpi, he donated a piece of land to the Augustinians which led them built a monastery better known in history as San Agustin de Manila, one of the jewels of colonial architecture in the country. They were also given missions in the Tagalog regions including also Ilocos, Pampanga and Batangas. Through the years, the Augustinians were always the most numerous and most compact in terms of mission" (Gutierrez, 2000, pp. 17-21).

Second to the Augustinians were the Franciscan missionaries. They arrived in Manila at 1578. From there "they spread in different places and established missions such as in Sta. Ana, Paco, Sampaloc, San Juan del Monte, Pandacan and even Laguna Bay and some districts in Morong. Further south was also entrusted to them such as Quezon, Camarines Norte, Camarines Sur, Albay and Sorsogon. In 1768, the government assigned to them the Jesuit missions in Samar in 1843, they took care certain towns in Leyte. The Franciscans were noted above all from many outstanding institutions of charity which they founded or administered" (Fernandez, 1988, pp. 21-22). In addition, one of the greatest achievements of the early missionaries was precisely the "creation of new civilization in the Philippines, a typical town so common today in our country where in there is a plaza, the church, the town hall, the school" (Gutierrez, 2000, pp. 23-24). The Franciscans were also notable to have "initiated the "escuelas de nińos" to educate the and train the children of natives" (Pilario \& Vibar, 2015, p. 145).

After the Franciscans, the Jesuits came to the country in the company of the first bishop of the Philippines, Domingo de Salazar, O.P. in 1581. For some time, "they lived in Lagyo, a district between Ermita and Malate, Manila. Soon they settled in what later would know as Intramuros in a place called Puerta Real, the compound where the Pamantasan ng Maynila is presently located. They accepted the missions in Taytay and Antipolo in 1591. Soon they accepted the islands of Samar, Leyte and Bohol as their main field of missionary activity. In Manila, they also accepted missions and created Santa Cruz and San Miguel and developed Quiapo, a native community at the time of arrival of Spain. The Jesuits started to assist the people in their spiritual needs, taught them the Christian Doctrine and created roving teams to reach out more people to preach the Good News. They

14 Consortia Academia Publishing (A partner of Network of Professional Researchers and Educators) 
Kristiyanong Pinoy: A glimpse on the history of evangelization towards renewed catechesis in the Philippines

even reached in Zamboanga in 1635 and even in the islands of Sulu and Cotabato out of their zeal and generous spirit. Sadly, their missionary work in the Philippines came to an end when they were expelled from the Spanish overseas dominions. King Charles III of Spain, due to the hatred of the bourbon monarchies of Europe against the Jesuits, ordered their expulsion from the Spanish dominions and it took effect in 1768. The missions in Samar and Leyte were turned over to the Franciscans while Bohol and Mindanao to the Recollects. The Jesuit parishes in Manila were taken over by the Filipino secular priests. The first period of the Jesuit presence in the Philippines came to an end. Their expulsion meant a terrible loss to the country especially in the missionary and educational aspects" (Gutierrez, 2000, p. 25-28). The Jesuits also "put up catechetical institute in Tigbauan, Iloilo and eventually founded and institute of higher learning- the Universidad de San Ignacio who dominated the educational system of colonial Manila until the mid-18th century" (Pilario \& Vibar, 2015, p. 145).

Another group of missionaries came to the Philippines, the Dominicans. The first Dominicans to come to the country were Domingo de Salazar, the first bishop of the Philippines. On July 25, 1587, Feast of St. James the Apostle, the patron of Spain, they entered Manila. "On that year of their arrival, after founding their motherhouse in honor of Santo Domingo, they went on various provinces in the Philippines. The process of Christianization was accelerated. They began their mission in northern and central Luzon namely in Pangasinan, Cagayan Valley, Tarlac, Bataan, Isabela, Babuyanes, Batanes and Mountain Province” (Gutierrez, 2000, p. 2830). Consequently, the Dominicans "excelled principally in their educational endeavors and famous missions abroad" (Fernandez, 1988, p. 25). One of these, "through the efforts of Archbishop Miguel de Benavidez, O.P, is the establishment of the first and only pontifical university in the country and in Asia, the University of Santo Tomas in Intramuros" (Pilario \& Vibar, 2015, p.145). Later, "with the increase of number in students' population and the need to accommodate additional courses, it had to procure a new campus outside Intramuros in Sulucan Hills, now Sampaloc Manila for its structural expansion" (Fernandez, 1988, p. 152).

Lastly, the major order came to the Philippines and played also a very important role in evangelization of the Filipinos was the Recollects. "Ten priests and four brothers arrived in Cebu in May 1606 and in June of the same year they were in Manila and built a convent and a church. They reached the provinces of Zambales, Mariveles and even Bolinao to spread the faith. In 1768, when the Jesuits were expelled from the Philippines, the missions in Mindanao and Bohol were taken over by the Recollects. The bishop of Cebu also entrusted to their care the mission in Palawan, but it did not flourish well until the 19th century due to the piratical raids of the Moros in Southern Philippines. In 1848, they took charge in the big island of Negros, and they sent there many missionaries who were experts in agriculture and the technical sciences. In this place, the Recollects left the greatest mark" (Gutierrez, 2000, p. 34-36). With these, the Recollects "were able to overcome the sectaries of Islam, with the enthusiastic cooperation of their Filipino faithful and the dedication of their religious who gave their lives in the effort" (Fernandez, 1988, p. 26).

These five major religious congregations shed the light of the faith in the Philippines during the three hundred years in the Spanish regime. But aside from these religious friars, other religious groups also came to help in the propagation of the faith such as the Fathers of San Juan de Dios in 1641, the Vincentians in 1862, the Capuchins in 1886 and the Benedictines in 1895.

\section{History of the Catholic Church in the Philippines}

\subsection{The Catholic Church and Education in the Philippines during Spanish Times}

According to some historians, the religious missionaries came to evangelize the Philippines through opening of schools as they considered these as means to win souls for Jesus Christ, to form learners in the Christian Doctrine and Good Conduct. In the beginning, "children were satisfied only in oral teaching for there were no books during those times. When few books came for instruction, the religious also trained some bright, perceptive Filipinos who would teach the basics: how to read, write, count and above all, the Christian Doctrine. 
These were held in the Parish Church, in the convent or in some instances, in the open air" (Fernandez, 1988, p. 5354). In addition, "the missionaries also believe that it is essential to begin the catechesis or education of faith to children for they are the basic cell of the society, and they are open for change totally. They became important support system of the missionaries by encouraging their parents to accept the Christian faith and denouncing pagan practices" (Gutierrez, 2000, p. 99).

One of the great innovations during the early years of the evangelization in the Philippine islands is "the teaching of the faith in the native language, particularly in Tagalog aside from Spanish and to come up with a catechism for the instruction of the faith to the people. It was raised and discussed during the Synod of Manila in the years 1581 to 1586 by the first bishop in the Philippines Archbishop Domingo de Salazar, OP. This is a great move in teaching the faith for the natives were to be instructed in their own language to easily understand the Christian message. Fray Juan de Plasencia, a Franciscan and an expert in language and customs of the tagalogs, composed a grammar and vocabulary and finally, he translated in tagalog the catechism or what later came to be known as the Doctrina Christiana" (Gutierrez, 2000, p. 41, 53-55). It is an effort to adopt a uniform or standard text and method in catechizing the Filipinos. This was published by the Dominicans in their printing press in Binondo in 1593 in Tagalog Spanish and in Chinese language. It teaches the basic prayers such as the Our Father, Hail Mary, the Salve, the Creed, the 14 Articles of Faith as well as the seven sacraments, seven capital sins, seven corporal and seven spiritual works of mercy, the Ten Commandments and the Five Commands of the Church, the Act of Contrition and 33 other questions in the faith. In this way, the teaching of the faith becomes inculturated.

Moreover, the missionaries also used their normal method in evangelizing which is practical is to require all Christians to go to Mass on Sundays and Feast days and listen to catechesis before or after the Eucharistic Celebration. It was demanded so that all will know by heart the Christian doctrine and to understand the faith more, it is required to have questions to the learners, a kind of public oral exam. As fruit of efforts of the missionaries to implant the faith on solid ground, the early Filipinos acquired a deep knowledge of the Christian religion. They received the faith with joy and understanding. Every religious congregation performed and applied their respective charism and worked generously and consistently to form adequate Christians" (Gutierrez, 2000, pp. 101-102, 106).

But on the other side of the coin, historians and educators also says that "despite the well-meaning efforts of the friars during the early Spanish colonial period, certain indigenous practices, beliefs, and traditions were altered, replaced, or forgotten due to evangelization. The "babaylans" were vilified and disempowered in the process of evangelization. Some feminists and gender rights activists also blame Christianity for the introduction of patriarchal social structures and the prevailing conservatism of the country when it comes to women and gender issues. The Christianization of the country has also led to the marginalization of non-Christian narratives in Philippine history" (Santos, 2021, \#5).

\subsection{The Catholic Church and Education in the Philippines during the American Rule}

The arrival of the Americans made sweeping changes in the educational system in the Philippines. If during the Spanish colonial rule, the teaching of the faith and religion is required or mandatory, it was banned during the time of American Public-School System. "The promulgation and implementation of the "Organic Act of 1900" headed by William Howard Taft, created the Department of Public Instruction that controlled all schools in the entire country. One of the controversial policies of the said institution is the prohibition of the teaching of religion in public schools" (Pilario \& Vibar, 2015, p. 146). But because of the anxiety of the Americans to mollify the Catholics and warm them up to the public-school system as much as possible, William Howard Taft proposed the "Faribault Plan" as form of compromise to the Philippine Catholic Church. The plan "enables the minister or parish priest in that certain pueblo where a certain public school is situated, either by person or by a designated teacher or catechist, to teach religion or catechesis for half an hour for three times per week provided that the parents of the students willfully gave their consent in written form to allow their children to attend the

16 Consortia Academia Publishing (A partner of Network of Professional Researchers and Educators) 
Kristiyanong Pinoy: A glimpse on the history of evangelization towards renewed catechesis in the Philippines said religion classes. But no public-school teacher shall be allowed to teach religion" (Sunga et al., 2000, p. 265).

Another problem rose during those times in the propagation of the faith was "the arrival of a big number of Protestant preachers from the United States, for around 600 trained American teachers aboard the vessel Thomas, American-styled education dominated the country. They were called the Thomasites and were assigned in all areas in the country to teach the American education to the Filipinos. From there, a new medium of instruction and subject in Philippine education was introduced, the English language" (Pilario \& Vibar, 2015, pp. 146-147).

The prohibition of the teaching of religion in the public-school system resulted a great conflict between the Catholic Church and the American Civil Government. "The superintendent during that time in Mania even reached the point of ordering the prohibition of devotions and removing school's crucifixes, religious emblems, sacred pictures etc. obviously against the Christian faith in the interest of Protestantism. One problem also on the part of the native priests is that they were not yet knowledgeable in the English language that is why they cannot penetrate fully in the public school system to preach and propagate the faith for there were no available and trained catechists during those times for the absence of catechetical formation for the catechists. Sadly, due to poverty and financial difficulties in the Filipino families, they have no choice but to transfer their children to the public schools which at the end, resulted and alienation between the Filipinos and the Catholic Church" (Sunga et al., 2000, pp. 266-267).

But despite the trouble and challenge brought by the American regime in prohibiting the teaching of the Christian faith, the Catholic Schools continued to function and bring forth their mission of spreading the Christian faith. "Most of the Catholic schools run by the foreign missionary orders maintained their schools through financial aid from abroad. Some schools, such as Ateneo de Manila, retained Spanish as medium of instruction in the early years but eventually and gradually, they adjusted themselves to the new trend, to adopt the English language as part of curriculum and language of instruction. Another movement that made Catholic Education remain firm and strong in spreading the Good News despite the persecutions is the providential arrival of other new religious congregations in the country with the purpose of either establishing works of charity or assisting their brother congregations here in founding of more Catholic Schools.

The role of religious women during this period is remarkable in the light of furtherance of Catholic Education such as: the Belgian Sisters or ICM s in 1910 who joined the Congregation of the Immaculate Heart of Mary or CICM fathers, the Holy Spirit Sisters or SSpS in 1912 who joined the Society of the Divine Word or SVD fathers, the Sisters of St. Paul de Chartes or SPC in 1904, the Benedictine Sisters or OSB in 1906, and the Franciscan Missionaries of Mary or FMM as well as the Good Shepherd Sisters or RGS in 1912. Their schools eventually opened aided greatly in promoting and strengthening the Catholic Education among the youth. Other schools established by other religious women during this time were the Assumption College run by the Religious of the Assumption Sisters in 1892 and the St. Scholastica's College in 1906 by the Benedictine Sisters. Likewise, new boys' school was also established in Manila were the La Salle College by the Christian Brothers of New York in 1911 and San Beda College by the Benedictines in 1901" (Sunga et al., 2000, pp. 269-272).

Some efforts were also made to upgrade the quality of instruction and formation of faith such as "changing of old textbooks for new ones and the adoption of English as the new medium of instruction and the acquisition of modern and best facilities to provide excellent education to the students such as beautiful and state of the art buildings, up-to-date laboratories and clean and excellent dormitories. These innovations served as opportunity for the Catholic Church to render great service to people for there will come a time that many years after, the public-school system could no longer accommodate all the children who seek education. The Church can save thousands of young people the disappointment that follows education in so many commercialized schools" (Sunga et al., 2000, p. 282). The gradual process of modernization and upgrading of Catholic Schools "provided an added attraction to a great number of students who began to flock to these schools to avail themselves of the best religious, cultural and professional formation" (Pilario \& Vibar, 2015, p. 152).

But the challenge continues to persist in the Catholic Church in aiming to propagate the faith. The 
compromise offered by the Philippine Commission under Taft administration "failed due to the hostile attitude of the Masons and aggressive Protestant denominations that influenced the Department of Education. The Church, in response, maintained the campaign in 1936 to make possible the real implementation of the provision on religious instruction in the 1935 Constitution which states in Article XIII Section 5 the "optional religious instruction shall be maintained in public schools as now promulgated as law". In 1938, the Congress passed the bill requiring the curriculum of all public schools to include a subject on Good Manners and Right Conduct or Character Building with excuse or exemption to some religious organizations on their children to attend religious instruction by their own denomination. Sadly, the said bill was vetoed by President Manuel L. Quezon on the ground that the bill was unconstitutional. This decision did not weaken the hearts of the Catholic Church hierarchy and many Filipino Catholics. Archbishop Gabriel M. Reyes of Cebu and other bishops of the ecclesiastical province made a pastoral statement that strongly disagreed with President Quezon's veto and assertion that the bill was not constitutional. Although this action by the Church hierarchy did not change the mind of the President, the efforts and persistence of the Church and a good number of educated Catholics, proved that the Catholic Church was no longer willing to be a sitting target for the attacks by the adversaries of faith" (Pilario \& Vibar, 2015, p. 154-155).

\subsection{The Emergence of Catechetical Reforms in Philippine Catholic Education}

With the challenge of teaching the faith especially in public schools, catechetical instruction became a growing priority of the Church hierarchy starting at the final years of American rule. Archbishop Michael O'Doherty "explained in one of his meetings in 1943 with his clergy, "The great need for Catholic Action in the Philippines at this time is: first, the teaching of catechism, particularly to the young attending schools where religious instruction is not given. It is also essential to form and train groups of catechists to impart this life-giving knowledge to the rising generation... As a matter of fact, times of adversity and affliction are often more fruitful for religion than prosperous and happy times. Let nothing discourage us or deter us from our first duty as priests- shepherds of souls- to preach and teach the Gospel" (Sunga et al, 2000, p. 357-358). This gave way to the founding of the Catholic Educational Association of the Philippines or CEAP in the year 1941.

The launch of the organization, spearheaded by Archbishop O'Doherty of Manila, addresses the "need for the Catholic Church to be better organized in the education field, having one voice for the Catholic schools to establish prominence in educational system in the Philippines. In his speech to the association's inaugural convention, Archbishop O'Doherty expressed: “this organization will not merely influence the currents of education, but also to broad stream of catholicity, which has always energized the process of national life... let us not forget to instill in the minds of the youth the knowledge of religion. It is also important to emphasize the relevance of catholic action as participation in the apostolate of the Church." With this, vigor and hope emerge in the Catholic Education until the Japanese invasion happened which ended it for some time for many schools together with some Church institutions such as hospitals, orphanages and Churches in Manila were destroyed because of war. In the Post World War II, the Church faced an immense task in rehabilitating and reconstructing damaged structures and CEAP offered its own personnel and facilities to make inspections of Catholic schools on behalf of the Office of Private Education. Another achievement done by the CEAP is the opposition to the bill proposed by Senator Roseller Lim in the Senate sought to prohibit foreigners from heading Philippine schools or "Filipinization". CEAP opposed it for the ground that the bill is against liberty and rights of the Church. Instead, they proposed for gradual and spontaneous Filipinization of schools through demonstrated merit" (Pilario \& Vibar, 2015, pp. 155-157).

The aspirations and love for catechetical instruction and religious formation was continued "through the realizations of Archbishop Rufino Cardinal Santos on the lack of trained and formed catechists which lead to inefficiency of programs in catechetical instruction. He worked to establish centers for the training of catechists. In 1963, he gave permission for the Franciscan Missionaries of Mary or FMM Sisters to establish the "Lumen Christi Catechetical Training Center based at the Our Lady of Loreto College. After two years, Cardinal Santos established the Institute of Catechetics under the care of Fr. Lino Banayad SJ and housed at College of Santa

18 Consortia Academia Publishing (A partner of Network of Professional Researchers and Educators) 
Kristiyanong Pinoy: A glimpse on the history of evangelization towards renewed catechesis in the Philippines

Isabel. It served as in-service training site of the Archdiocesan Confraternity of the Christian Doctrine. In 1967, the good archbishop gave permission to the "Mother of Life Catechetical Center" to operate under the Notre Dame de Vie (NDV), a secular institute. However, another problem with regards to catechetical program that relies on sole volunteerism is the rapid turnover of catechists. This was what Archbishop Jaime Cardinal Sin saw during his term in the Archdiocese of Manila. Then, he ordered a great shift towards the professionalization of catechists, which means the employment of paid catechists. Years after the 1979 Synod, Cardinal Sin founded the Archdiocesan Catechetical Office and gave mandate for a feasible remuneration system for catechists" (Sunga et al., 2000, p. 356-359).

\section{A Renewed Catechesis and Religious Education: A Gift to the Church in the Philippines}

After many years in the life and mission of the Church in the Philippines, it is still evident that the teaching of the faith or religious education must undergo renewal in order that the education of faith be enhanced or revitalized, and that catechists and religious educators have the spirit of zeal and joy in the proclamation of the life of Jesus Christ. It is part of the mission mandate of Christ, before He ascended into heaven, who told to His disciples to "go, therefore, and make disciples of all nations, baptize them in the name of the Father, and of the Son, and of the Holy Spirit, teaching them to observe all that I have commanded you. And behold, I am with you always, until the end of the age" (Matthew 28:19-20). Therefore, catechesis is a great task of the Church for it is "the practice or actual transmission of the message of Jesus Christ" (Peńa, 1982, p. 9). The Church's goal is to make all Christians "be educated in the faith, particularly the teaching of the Christian faith passed on in an organic and systematic way, with a view to initiating the hearers into fullness of life" (John Paul II, 1979, \#18). In line with this, the Church in the Philippines underwent a series of reflection and renewal in catechesis and religious education. This paper will focus on the two most historical movements in the renewal of catechesis in the Philippines namely: (1) the National Catechetical Directory for the Philippines in 1984, (2) and the well-known Acts and Decrees of the Second Plenary Council of the Philippines in 1992.

\subsection{The National Catechetical Directory for the Philippines (1984)}

In 1971, Pope Paul VI endorsed the General Catechetical Directory (GCD) which provided basic principles and guidelines in the catechetical ministry of the Universal Church. This catechetical document "gave task to national bishops' conferences to come up with a national catechetical directory incorporating more recent developments in catechesis and religious education in the context of certain country" (Episcopal Commission on Catechesis and Catholic Education, 1984, Preface C). This is the beginning of the crafting and promulgating the first national catechetical directory for the Philippines entitled "Maturing in Christian Faith". This catechetical directory prepared by the Episcopal Commission on Catechesis and Catholic Education or ECCCE as response to the call of the renewal movements in the Universal Church such as the recently concluded Second Vatican Council and the post synodal apostolic exhortation of Pope John Paul II entitled "Catechesis in our Time" or "Catechesi Tradendae" in 1979.

The catechetical directory tacked many concerns in the teaching of the faith. It highlighted "the importance of not just memorization or the doctrine aspect of the faith, but also including the orthopraxis or the application or living the faith as well as prayer life and sacraments, making a difference between catechesis and theology" (Episcopal Commission on Catechesis and Catholic Education, 1984, \#58). It also emphasizes the "essence of catechesis for after the initial conversion proclamation, catechesis is the subsequent activity with the twofold objective of maturing the initial faith and continuous education of true disciples of Christ". It makes clear that catechesis is vital and integral part of evangelization" (Episcopal Commission on Catechesis and Catholic Education, 1984, \#61\& 63). Therefore, the catechist must "focus only on handing over the essential of the Christian message and effectively communicate it in an inculturated way directed to a specific level of maturity and development of those being catechized" (Episcopal Commission on Catechesis and Catholic Education, 1984, \#68-69). Inculturation also demands "making our Filipino cultural values more attuned and configured in the Gospel of Christ" (Roche, 1999, p. 39). 
In addition, it is also the goal of catechesis "to instruct the catechized that they can see for themselves, their own daily acts, problems, hopes and dreams the light of basic Christian truths. At the end, the goal of catechesis is to put people not only in touch, but in communion and in intimacy with Jesus Christ, the heart and Person of catechesis" (Episcopal Commission on Catechesis and Catholic Education, 1984, \#75 \&77). It also raised the importance of "witnessing in catechesis, for living an example to the learners as proof of authentic and matured Christian life is needed... to be credible teachers of faith and make Christ present in the contemporaries will make catechesis more attractive and effective" (Episcopal Commission on Catechesis and Catholic Education, 1984, \#105). In this way, the Catholic Schools can address "the problems regarding the issues or problems on catechists for some cannot teach of their own lives or experiences, lacking training on how to give concrete and specific examples from the experience they share with those they catechize... leading towards a "gap" between experiential catechesis and actual practice" (Roche, 1999, pp. 40-41).

The directory also explained that the bishop of every diocese is the "prime catechist, the one who foster active and effective catechesis... to maintain real passion embodied in a pertinent and effective organization" (Episcopal Commission on Catechesis and Catholic Education, 1984, \#475). It also calls for the Catholic Schools to "provide the best opportunities for a continuing and systematic catechesis which will be successful if the teachers are well competent and motivates spiritually from within by personal religious dedication, a good program or curriculum in religious education and lastly, the cooperation and participation of the whole school community, the administration, the faculty and integration of the whole school curriculum and student activities in the light of faith. Catechists must also have professional training and continuing educational formation and development and adequate salaries for religious motivation is certainly necessary for successful teaching of the faith” (Episcopal Commission on Catechesis and Catholic Education, 1984, \#479-480).

Since the publication of the 1984 NCDP, many new advances and initiatives have arisen which substantially affect the catechesis or education of the faith in the Philippines. Most important are the publication of the Catechism of the Catholic Church in 1994, the revision of the 1971 General Catechetical Directory in 1997 entitled the General Directory for Catechesis (GDC), the issuance of significant Church documents in the Philippines such as the Acts and Decrees of the Second Plenary Council of the Philippines (PCP II) in 1992 and the national catechetical book entitled Catechism for Filipino Catholics in 1997 and lastly, the promulgation of the Compendium of the Catechism of the Catholic Church by Pope Emeritus Benedict XVI in June 2005. With these renewed efforts in the catechetical ministry over the past twenty years, the bishops in the Philippines, particularly the Episcopal Commission on Catechesis and Catholic Education of the CBCP, decided to revise and update the present catechetical directory entitled the New National Catechetical Directory for the Philippines (NNCDP) in 2007 to focus more deeply in inculturation and in collaboration with the national Catechism, the CFC. NNCDP 2007 presents "a balance approach that integrates the legitimate concerns for the Gospel message and its effective communication to the Filipinos today" (Episcopal Commission on Catechesis and Catholic Education, 2007, \#45).

In addition, the NNCDP aims to stimulate and inspire new efforts in catechesis by highlighting "Integral Faith Formation" which is the top priority among the pastoral concerns of the Church. It also expressed the urgency that catechists and religious educators must teach the faith in epiphanic way rather than argumentative, integral or whole in all aspects and most importantly, by witnessing, for Pope Paul VI observes: "Modern human being listens more willingly to witnesses than to teachers, and if they listen to teachers, it is because they are witnesses". To be witnesses of the Gospel, catechists must be "formed in a deep love of God revealed in Jesus Christ so that they may be inspired to become creative, imaginative, ongoing and exploring new methods, new fervor, new expressions and even new means of social communication for more effective instruction of the Good News especially to the young generation" (Episcopal Commission on Catechesis and Catholic Education, 2007, \#79). Hence, the role of catechist is to be an "essential component of the Church's evangelizing mission which is to deepen the faith that evangelization invokes... The role of the catechists and religious educators is to echo not personal opinions or attitudes, but the message of Christ, the Lord's self-disclosure of love or revelation to the whole world" (Natividad, 2018, pp. 25-26).

20 Consortia Academia Publishing (A partner of Network of Professional Researchers and Educators) 
Kristiyanong Pinoy: A glimpse on the history of evangelization towards renewed catechesis in the Philippines

\subsection{The Acts and Decrees of the Second Plenary Council of the Philippines (PCP II)}

On January 20 to February 17, 1991, a significant moment in the Church in the Philippine happened at the San Carlos Pastoral Formation Complex at Guadalupe, Makati. This is the Second Plenary Council of the Philippines or better known as PCP II. Fr. Pedro Achutegui, SJ (1991), in his book entitled "121 Questions and Answers on the Second Plenary Council of the Philippines, explained the reasons why the Philippine bishops decided to hold a plenary council during those times: First, it is a "need for updating or aggiornamento after the Second Vatican Council or Vatican II. Second, the signal pronouncements of the Supreme Pontiffs and the several synods of bishops held in Rome since 1967. Third, the significant development in Ecclesiology and the promulgation of the new Code of Canon Law and lastly, the social and religious changes in our time, particularly in our country" (p.11). In addition, Bishop Teodoro Bacani (1991), the auxiliary bishop of Manila during PCP II, also saw the urgency that "the Church in the Philippines is in urgent need of renewal and revitalization in the faith... for there is an appalling religious ignorance of a vast number of Catholics, the lack of trained catechists, the clergy-centeredness of the Church life in the parishes and the organizations, the reality of poverty of the majority of people despite the richness of the country, the very obvious social injustice evident in the misdistribution of wealth, power and opportunities which concludes that many Christians still have not been living up to their Christian call as communion of love" (pp. 6-7).

PCP II had a great contribution in the renewal of education of faith for the Filipinos. With this reality in Christian formation, it is necessary that religious instruction or catechesis must be "integral" or holistic, not only teaching the minds on the various doctrines and teachings of the faith, but the challenge is on how to live these teachings of Jesus Christ and develop a deeper sense of God in prayer and sacramental life. This is how essential catechesis for "the Church is the messenger of the Gospel, but she begins by being evangelized Herself... She has a constant need of being formed and evangelized, if She wishes to retain newness, vigor and strength to announce the Gospel" (Catholic Bishops Conference of the Philippines, 1992, \#154). Thus, renewed catechesis is the "primary element of a renewed integral evangelization... It must be (1) Christocentric and rooted in the Word of God for nothing can speak better of the Incarnate Word of God than the Scriptural Word of God which is the primary catechetical book. (2) It should also be inculturated and would need that the Gospel be preached in the words of the people for without such action, either the Christian message remains unknown to the Filipino or the Filipino in accepting it risks alienated from his way of life. And lastly (3), catechesis must be systematic or presented in an efficient and programmed way the entire Gospel from the Bible and Tradition as taught by the Church without misrepresentation or reduction, highlighting the basics of Catholic belief and practice" (Catholic Bishops Conference of the Philippines, 1992,\#156-163).

In addition, renewed catechesis would not be enough, for renewed integral evangelization also demands "renewed social action and renewed worship". PCP II tells: "The Church evidently recognizes that Christian Social Action, i.e., action carried out by the Church and its members to promote human progress, justice in society and peace, is a task without which evangelization is not integral or holistic... While the third area of renewal is worship. Renewing the worship life requires renewing our prayer life" (Catholic Bishops Conference of the Philippines, 1992, \#165, 167 \& 169). It is also important to remember for every catechist and religious educator to have the interrelation and integration of the three various renewals... that catechesis must not be isolated from social action and prayer life (Catholic Bishops Conference of the Philippines, 1992, \#182). This demand from PCP II is also noticeable in the teaching of Thomas Groome (2011) in his reflection on the goal of catechesis as holistic Christian faith and life in the way of "Head, Heart and Hands". He said: "...First, the way of Head speaks about discipleship of faith seeking understanding and trust with personal conviction, continued by learning and investigation, by searching and reflecting, by discerning and deciding, all toward spiritual understanding for life. Second, the way of the Heart claims a discipleship of just relationships and right desires, community building, kindness and inclusion, trust God's love, and prayer and worship. Lastly, the way of the Hands demands a discipleship of charity, justice, peacemaking, simplicity, truthfulness, healing and contrition" (p. 111). 
At the end, PCP II reminds all educators of faith that renewed evangelization's most significant characteristic is the emphatic recognition of the primary role of the Holy Spirit in evangelization. The Holy Spirit is the principal Agent of evangelization... It is the Holy Spirit who impels everyone to proclaim the Gospel and it is $\mathrm{He}$ who in the depths of consciences causes the word of salvation to be accepted and understood. Catechists must always keep in mind to always pray to the Holy Spirit for He will ensure the continuity and identity of understanding amid changing conditions and circumstances" (Catholic Bishops Conference of the Philippines, 1992, \#212-214). The best thing to do for religious educators is to do their best in teaching the faith and always ask the guidance and will of the Holy Spirit, the Teacher of faith.

\section{Conclusion}

The history of Christianization of the Philippines is truly a great celebration and milestone in the Catholic Church. Among the nations in Southeast Asia, the Philippines is "noted as the only predominantly "Christian country" graced with gift of Christian faith" (Episcopal Commission on Catechesis and Catholic Education, 2007, \#20). Through the efforts of the missionaries who wanted to spread the Good News of Christ, the Filipinos received this grace coming from Christ and accepted His love and mercy. As the Filipinos move towards the 500 years of this momentous event, the Church must continue to nurture this gift of faith from God especially in these challenging times that people "seem to become more secular than ever, with clear increased stress on materialistic values, consumerism and globalization." (Roche, 2008, p. 18). There are still many things to be done in the ministry of catechesis. As the Church moves Herself for renewal, catechists and religious educators must never stop in being zealous in the propagation of the faith. Nowadays, learners "do not only want to be nourished when it comes to doctrines, but they have "spiritual hunger" and searching for wholeness and meaning in life" (Huang, 1999, p.53). Aside from the "traditional" ways of teaching the faith, which was inherited to history, the Church must continue to innovate and be inspired in seeking various ways to make the faith valuable and meaningful to the lives of all Christians, especially the young people. They love to hear stories, experiences, and testimonies of faith. This is what they want to hear and from this, they will be enforced and inspired to be bearers of the Gospel of Christ and see also the works of God in their daily lives. On these, The Church fulfils Her mission to proclaim that faith "is truly a gift from God... but it is also a human response and action for God" (Bacani et al, 1990, p.27).

At the end, the goal of evangelization and catechesis is to make "all Christians to receive the Gospel and have fullness of life, as St. Irenaeus of Lyons would tell, "The glory of God is a human being fully alive" (Barron, 2018, \#2). A person who is being catechized has "a period of formation and apprenticeship in Jesus Christ" (Congregation for the Clergy, 1997, \#63). Lastly, catechesis and religious education, to address the signs of the times, must also promote inclusive atmosphere that is open for interreligious dialogue. The Church, through the Catholic Schools, must be a place where learners, no matter what religion, sex, color they may have, must inculcate values for moral development and equality amidst differences.

\section{References}

Achas, A., \& Salmorin, M. (2014). Methods of Research. Mindshapers Co. Inc.

Achútegui, Pedro S. de. (1991). 121 Questions and answers on the Second Plenary Council of the Philippines. Manila: Cardinal Bea Institute, Ateneo de Manila University.

Bacani, T. (1991). Towards the Third Millennium: The PCP II Vision. Place of publication not identified: publisher not identified.

Bacani, T., Gregorio, C., \& Reyes, G. (1990). Working Paper on Religious Concerns for the Second Plenary Council of the Philippines. Commission on Religious Concerns.

Barron, R. (2018). The Glory of God is a Human Being 'Fully Alive'. Retrieved from https://www.wordonfire.org/resources/article/the-gloryof-god-is-a-human-being-fully-alive/320/

Berg \& Lure. (2012). LibGuides: Historical Research Method: Home. Edith Cowan University Library. https://ecu.au.libguides.com/historical-research-method 
Kristiyanong Pinoy: A glimpse on the history of evangelization towards renewed catechesis in the Philippines

Cacho, R. (2021). Rediscovering the Christian Story. A Flourishing Faith: Celebrating 500 Years of Christianity in the Philippines, 25-46. Don Bosco Press, Inc.

Catholic Bishops Conference of the Philippines. (1992). Acts and Decrees of the Second Plenary Council of the Philippines: Held at the Holy Apostles Seminary, Makati, Metro Manila from 20 January-17 February 1991. Manila: Published and distributed by Paulines Pub. House.

Catholic Bishops Conference of the Philippines. (2019). 500 Years of Christianity. Retrieved from https://cbcpnews.net/cbcpnews/500-years-ofchristianity/

Congregation for the Clergy (1997). General Directory for Catechesis: Vatican City: Libreria Editrice Vaticana.

Del Castillo, F. (2016). Gospel-Culture Relationship of Traditional Filipino Religion and Catholicism. https://doi.org/10.13140/RG.2.1.3208.2002

Del Castillo, F. (2021). Gifted to Give: Perspectives on Faith and the Catholic Church in the Philippines. Zeitschrift für Missionswissenschaft und Religionswissenschaft 105, 1/4, 159-170.

Episcopal Commission on Catechesis and Catholic Education. (1984). Maturing in Christian Faith: National Catechetical Directory for the Philippines. Pasay City. Daughters of St. Paul

Episcopal Commission on Catechesis and Catholic Education. (1997). Catechism for Filipino Catholics. Manila: Catholic Bishops Conference of the Philippines

Episcopal Commission on Catechesis and Catholic Education. (2007). New National Catechetical Directory for the Philippines. Manila: Catholic Bishops Conference of the Philippines

Fernandez, P. (1988). History of the Church in the Philippines (1521-1898). San Juan, Metro Manila, Philippines: Life Today Publications.

Groome, T. H. (2011). Will there be faith? A New Vision for Educating and Growing Disciples. New York, NY: Harper One, an imprint of HarperCollins.

Gutierrez, L. (2000). The Archdiocese of Manila: A Pilgrimage in Time (1565-1999) Vol.1. Manila: Roman Catholic Archdiocese of Manila.

Huang, D. P. (1999). Emerging Global, Postmodern Culture in the Philippines. Landas, 13(1), 47-58.

John Paul II. (1979). Catechesis in Our Time: Catechesi Tradendae. Boston, MA: Pauline Books and Media.

Maningas, I. (2003). Contemporary Approaches in Religious Education. Makati, St. Pauls Philippines.

Natividad, M. L. (2018). Teaching the Faith: Renewal in Religious Education in the Philippines. Quezon City: Claretian Communications Foundation.

Peña, B. (1982). Catechetics: The Proclamation of the Soteriological Message. [S.1. : s.n.], c1982. Retrieved from http://0search.ebscohost.com.lib1000.dlsu.edu.phlogin.a spx? direct=true \&db= cat00680a\&AN=dlsu.b1019379\&site=eds-live

Pilario, D. F. E., \& Vibar, G. G. (2015). Philippine local churches after the Spanish regime: quae mari sinico and beyond. Quezon City, Philippines: Adamson University.

Pontifical Council for the Promotion of the New Evangelization. (2020). Directory for Catechesis. Makati: Word and Life Publications.

Roche, J. (1999). The CBCP Pastoral Exhortation and Religious Education. Landas, 13(1), 37-47.

Roche, J. (2008). Practical Catechesis: The Christian Faith as a Way of Life. Quezon City: Phoenix Publishing House.

Santos, F. J. (2021). Remembering 500 Years of Christianity in the Philippines. The Diplomat. https://thediplomat.com/2021/03/remembering-500-years-of-christianity-in-the-philippines/

Sunga, E., Santos, R., \& De Jesus, A. (2000). The Archdiocese of Manila: A Pilgrimage in Time (15651999)

Vol.2. Manila: Roman Catholic Archdiocese of Manila. 
Quimson, L. O., Jr.

24 Consortia Academia Publishing (A partner of Network of Professional Researchers and Educators) 